Ruminants

\title{
Challenges of beef cattle production from tropical pastures
}

\author{
Dennis P. Poppi ${ }^{1 *}$, Simon P. Quigley ${ }^{1}$, Tiago Alves Corrêa Carvalho da Silva ${ }^{1}$, Stuart R. McLennan² \\ 1 University of Queensland, School of Agriculture and Food Science, Gatton, Queensland, Australia. \\ 2 University of Queensland, Faculty of Science, Queensland Alliance for Agriculture and Food Innovation, Brisbane, Queensland, Australia.
}

\begin{abstract}
The live weight gain of cattle on tropical pastures is reviewed and found to be low and dependent on the length of the growing season. Supplements may be added to address the primary limiting nutrient, which, in the dry season, is crude protein. The response relationships of live weight gain to level of supplement (protein or energy) that have been developed for animals on pasture in Brazil and Australia have been compared and found to be very similar. This gives confidence in recommending a supplementation strategy for cattle on tropical pastures. Response in the wet season was very low and likely to be uneconomic compared with dry season supplementation. Supplementation is costly and should only be used as a last resort, but the strategy needs to be viewed in the context of a growth path to a defined market or slaughter weight. In Australia, high inputs in the first dry season are risky as subsequent compensatory growth can reduce or eliminate the weight advantage of a supplement. There is less financial risk in using supplements towards the end of the growth path. Growth paths can follow many forms and there is no need to maximise live weight gain in each period. Targeted supplements in the second dry season, leucaena based systems, other special-purpose pastures or crops, and feedlots offer the most economical way for cattle to meet market targets. The expected annual live weight gain and weaning weight are other major factors which determine the growth path, target market which can be achieved, and the level of intervention (supplements, legumes, feedlots, etc) which are required and when. Some recent results on growth paths in Australia are presented.
\end{abstract}

Key Words: growth paths, legumes, pastures, skeletal growth, supplements

\section{Introduction}

Beef cattle production as annual live weight gain from tropical pastures is low compared with that which can be achieved from temperate pastures (Winter et al., 1991). The pasture dry matter (DM) production from tropical pastures can be much higher than that from temperate grasses, but with lower stocking rates and lower levels of utilisation as set by the phenology of the plant, this also equates to low production per hectare. The tropical region can be divided into wet tropics and dry tropics. Australia has only a very small proportion of wet tropics compared with Brazil and most of its beef production comes from a dry tropical environment. This is characterised by a distinct wet and dry season, both of variable length, with the dry season varying from around four months up to nine months of the year. The length of the growing season is the most

Received: December 27, 2016

Accepted: May 17, 2017

*Corresponding author: d.poppi@uq.edu.au

Copyright (c) 2018 Sociedade Brasileira de Zootecnia. This is an Open Access article distributed under the terms of the Creative Commons Attribution License (http://creativecommons.org/licenses/by/4.0/), which permits unrestricted use, distribution, and reproduction in any medium, provided the original work is properly cited. important factor affecting annual live weight gains with the concept of green days (McCown, 1981) most closely correlated with annual live weight gain. These conditions pose similar challenges in both countries, though there are some distinct differences. The most noticeable differences are the differences in the tropical grass species and the longer wet season in Brazil with a resultant longer period of adequate crude protein (CP). Stocking rate is also much higher in Brazil. The management strategies that both countries have adopted differ in that, on native tropical pastures in northern Australia, reducing stocking rate and maximising head performance has been the best option as it has enabled good pasture condition and maintenance of the pasture base, whilst maximising annual live weight gain (O'Reagain et al., 2011). Brazil differs in the dominant pasture species, especially a reliance on Brachiaria species, and the availability of cheap supplements in which to improve live weight gain.

The biggest drivers of profitability in any system are the annual live weight gain and the stocking rate and the balance between the two factors is what is required. In Australia, this has led to various recommendations of grazing both introduced and native grass species, e.g. the Wambiana project (O’Reagain et al., 2011) and Heytsbury 
project (Hunt et al., 2013). The principles for managing pasture and animals are the same across the various environments, which vary mainly in level of rainfall and pasture species, but the details on stocking rate, utilisation, and stocking method vary. Thus, Queensland can be divided into endowed, intermediate, and harsh zones based largely on rainfall and the pasture base (native or introduced pasture species). In these land systems, the traditional approach was to slaughter animals around the $550-600 \mathrm{~kg}$ live weight range, which, based on the annual live weight gains of 100-190 kg (Winter et al., 1991), means an animal is often $>3.5-4$ years of age at slaughter.

The challenge today is that markets require younger animals with variable carcase and fat cover specifications and if these are to be achieved, then annual live weight gain needs to be increased by faster growth in the wet season, the dry season, or a combination of both. This may be achieved by introducing legumes into the pasture, specialised crops, or supplements. The challenge in achieving this is by developing novel growth paths that reach the target weight for age and there may be a number of different growth paths that achieve the same end point. Therefore, there is no right or wrong growth path, but rather there are key decision points, largely set by live weight, along the path which determine whether the end point is achievable or what options are available to speed up or slow down the growth projection.

Understanding the whole growth path and options are the keys to managing the animal to achieve the end point profitably. It is very easy to manipulate growth paths to reach the new targets of younger animals $<2.5$ years at target weight and fat cover, but it is very hard to do this economically.

\section{Annual live weight gain}

The variability in annual live weight gain and the season variability that contributes to that were reviewed by Winter et al. (1991). This gave values of approximately $100-120 \mathrm{~kg} /$ year for native pastures, approximately 150 $180 \mathrm{~kg} /$ year for introduced grasses, and approximately $250 \mathrm{~kg} /$ year for leucaena-based systems which, except for the leucaena-based systems, are much lower than values achieved from temperate-pasture systems. This was largely due to variability in season (length of wet and dry seasons), but also in the live weight gain which is achievable from the best tropical pastures. These values in the wet season can be greater than $1 \mathrm{~kg} /$ day, but only for very short periods, maybe up to six weeks. This depends on pasture species of which Australian native pastures range from 0.2-0.8 kg/day; however, buffel grass (Cenchrus ciliaris) in the Brigalow region of Queensland results in $0.2->1.0 \mathrm{~kg} /$ day and over a much longer period. This is best characterised by the CP values from buffel grass pastures in Central Queensland and Mitchell grass pastures in the Victoria River District of the Northern Territory (Figure 1). These observations contrast the much lower $\mathrm{CP}$ values $(<6 \% \mathrm{CP})$ over a long period of about nine months on native pasture, whilst on buffel pastures, CP was $<6 \%$ CP for only about two months. Simple strategies of using urea work well on native pastures, but have no role on buffel grass pastures and addressing the low CP for only two-three months of the year may not be important in the overall growth path to slaughter from buffel grass pastures. A very important principle here is that live weight gain does not need to be maximised for all seasons in every year of the two-three years of a growth path to slaughter.

There has been a collation of data from Brazil (Dórea, 2010; Detmann et al., 2014; Barbero et al., 2015; De Oliveira et al., 2016) and these generally outline the same features: CP ranged from 3.4-21.0\% and live weight gain ranged from $-0.36-1.2 \mathrm{~kg} /$ day. Data from Brazil more closely aligned with that from the endowed zone of Queensland and not as harsh or challenging as that from the dry tropics of Australia. Having good data on annual and seasonal variation in live weight gain from pasture community types is essential to making good decisions and with better weighing facilities, both automated and manual, these should now be readily available. Quality

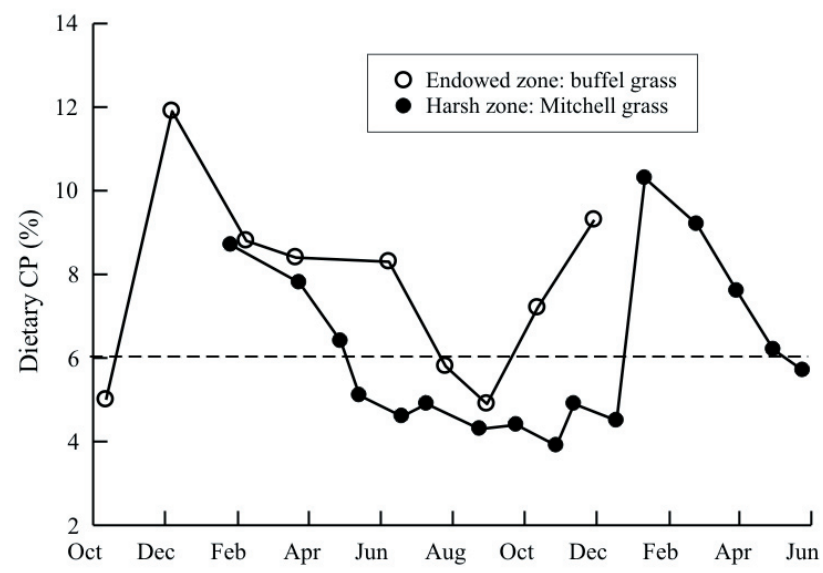

The dashed line indicates an arbitrary threshold of $6 \% \mathrm{CP}$ in the diet.

Figure 1 - Seasonal changes in the crude protein $(\mathrm{CP})$ content of the diet selected by steers grazing in the buffel grass in the Endowed zone or Mitchell grass in the Harsh zone of Queensland, as determined using faecal nearinfrared spectroscopy. 
control in a feedlot or intensive monogastric industry means understanding what is happening and grazing systems will need to develop such systems, preferably automated, so that appropriate decisions can be made early. Such realtime monitoring of animals is a common feature in the pig, poultry, and dairy systems and has revolutionised the feeding and management of those animals with marked improvement in efficiency and profitability (Black, 2014). There is no reason why extensive ruminant systems cannot move along the same path to better target type and amount of supplement, class of animal, and when or if to supplement at all.

\section{The target market determines the growth path}

The target market determines the growth path and there are many different growth paths to the same market or to different markets (Figure 2). In New Zealand, very different growth paths can also be used on temperate pastures to reach a similar target weight (Figure 3). A target high slaughter weight can be achieved at 3.5-4.5 years of age of the animal from extensive rangelands pastures in Australia with minimal inputs. This can be very profitable and was the conventional system of production in northern Australia to meet the ground meat trade in North America and still is the system of production in many regions (Stockwell et al., 1991; O’Reagain et al., 2011). It is still profitable and any

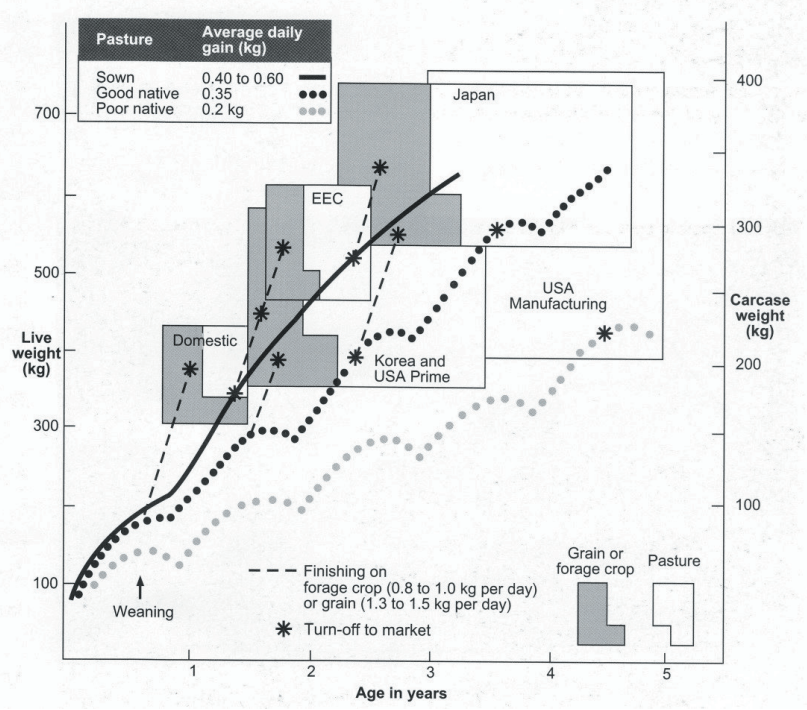

Figure 2 - Growth patterns of beef cattle on different pastures and the finishing options for various markets. Figure reproduced with permission, taken from "Grazing the North: creating wealth and sustaining the land", by Gramshaw, D. and Lloyd, D. (1993). CThe State of Queensland (acting through Queensland Department of Primary Industries) 1993. manager must compare the economics of this minimalist approach to an approach using higher input of supplement, introduced pastures, or special-purpose pastures or crops; in low soil fertility, low rainfall areas, this minimalist approach may still be the best strategy. However, the challenge from tropical regions is how to reach the better-quality market from either low- or high-quality pasture bases.

The Wambiana project (O'Reagain et al., 2011) is a long-running grazing experiment (18 years) in the tropical dry zone of Charters Towers in north Queensland, Australia. It was set up to examine different grazing management strategies (largely stocking rate and grazing systems of set stocking, rotational grazing, and pasture spelling) with minimal input of a urea supplement and to monitor the effect on pasture and land condition and the effect of such grazing management practices on soil runoff with detrimental impact on the Barrier Reef. A key feature of the tropics in Australia is the variable rainfall pattern which follows El Niño and La Niña patterns over decades. Set stocking and variable stocking rates are means to adjust animal requirement to feed supply without using energy and protein supplements. This study found that moderate set stocking (based on 20-25\% pasture utilisation) or variable stocking rate, by adjusting annual stocking rate to achieve a projected $20-25 \%$ utilisation of the pasture base, resulted in the best outcome for the environment (land condition and soil runoff), annual live weight gain,

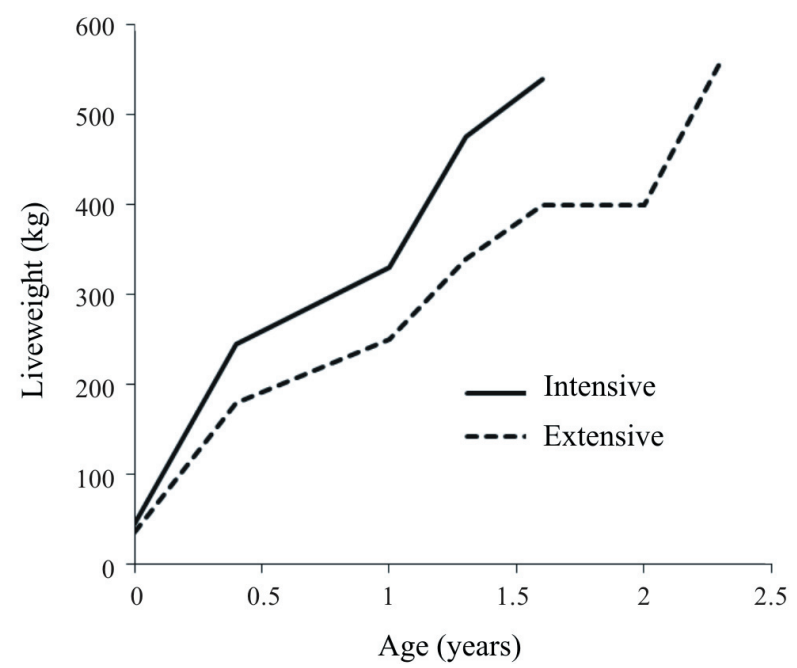

Figure 3 - Two pasture-based systems in New Zealand based on intensive or extensive temperate pasture management systems (A. M. Nicol personal communication, December 2016, Lincoln University, Lincoln, New Zealand). 
and profitability. Thus, reducing stocking rate to reach this level of utilisation achieved the best profit and the best biological outcomes in agreement with previous modelling by Stockwell et al. (1991). It is hard to adjust stocking rate for most cattle producers on an annual basis because of the large numbers of animals that need to be bought or sold and it is hard for them to accept the need or wisdom of having fewer animals if they do not focus on profitability rather than numbers of cattle. By contrast, the Pigeon Hole project (Hunt et al., 2013) on very extensive pasture-based systems in the Northern Territory showed that very large paddocks, with very uneven grazing distribution, had very high levels of utilisation near the riparian zones, but $>4 \mathrm{~km}$ from water, there was very low or no utilisation of pasture. Their analysis showed that in these large paddocks ( $>$ approximately $130 \mathrm{~km}^{2}$ ), there was uneven utilisation across the landscape resulting in an average utilisation of only about $10 \%$ of the pasture base. In that situation, smaller paddocks through better fencing would result in more even utilisation across the landscape and set stocking rate could be increased to reach $20 \%$ utilisation with no detrimental effect on land and pasture condition, but an obvious increase in profitability through the higher stocking rate with little change in annual live weight gain.

These two studies show that simple management, such as stocking rate and grazing distribution, allied to low-target pasture utilisation (usually around $20-25 \%$ for native or rangeland pastures) can achieve good production systems with modest annual live weight gains that, nevertheless, meet a specific market. Simple management in line with accepted principles can make a huge difference to the biological and economic outcome (Stockwell et al., 1991).

Meeting a better market requires more inputs if the pasture base is low. Given that annual live weight gains rarely exceed $200 \mathrm{~kg} /$ year on most tropical pasture systems, then high inputs are required throughout or at discrete times. These inputs are costly and inappropriate use may lead to large economic losses. The biology is simple, but the economics are more complex. In Australia, the new marketing system of Meat Standards Australia (MSA) means that animals need to be $<2.5$ years of age and target weight of around 550-600 kg if their carcase is to grade to the highest levels. Our challenge is to devise systems that will achieve that economically. It is easy to achieve biologically. Temperate pasture systems achieve this easily with no inputs (e.g. Figure 3) and the challenge in these systems is to increase pasture utilisation (to $70 \%$ ) through grazing management rather than any external inputs of supplements.
McLennan (2014) completed a series of growth path studies (Figure 4) on native pastures to achieve target weight at $<2.5$ years, which had some key conclusions:

Native pastures with only dry season urea supplement take $>3.5$ years to achieve target weight in line with results from over 50 years of research into conventional production systems in this northern region of Australia.

High energy and protein supplements in the dry season can enhance growth to the extent that steers reach target weights at $<2.5$ years.

A weaner needs to go through two dry seasons on its path to slaughter at $<2.5$ years of age and a decision needs to be made whether to supplement in both dry seasons, only the first dry season, or only the second dry season. Wet season supplementation has been shown to be uneconomic in this region (McLennan, 1997, 2002). This decision is complex and compensatory growth can erode most of the benefit of a dry season supplementation regime.

The length of the dry season is quite variable in this environment (or conversely the length of the wet season) and a supplementation regime in the first dry season of the growth path may be completely unnecessary or may be very important in achieving a target weight two years later, dependent on the length of the two dry seasons. For this reason, supplementation in the first dry season has high economic risks and a safer option is to use high inputs

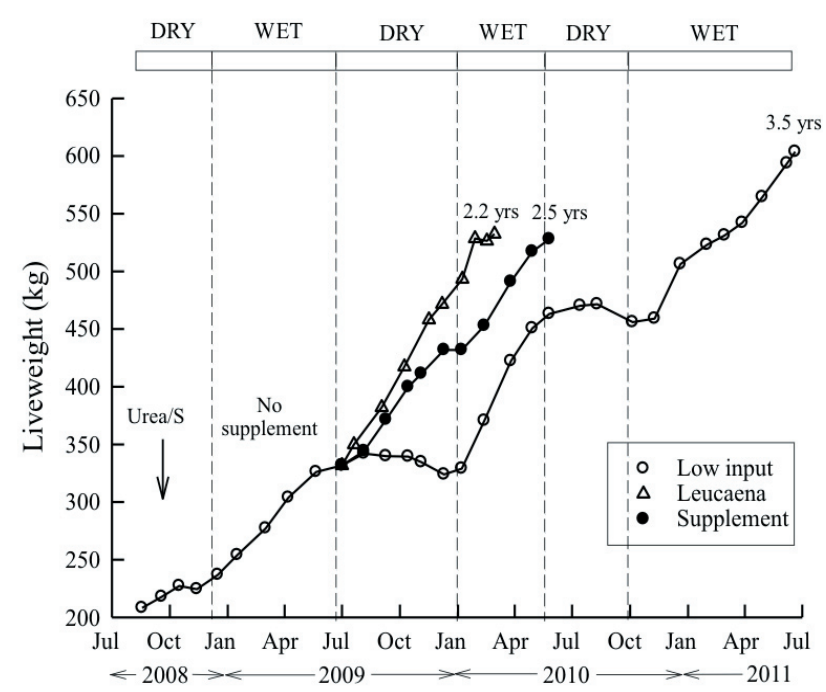

Figure 4 - Seasonal changes in the post-weaning liveweight of steers receiving various nutritional inputs where all groups received urea/S in the first dry season post-weaning and subsequently received no further supplement (Low input) or were fed high-level molasses/urea/copra meal supplement in the second dry season (Supplement) or were relocated to a leucaena/grass-based pasture at the start of the second dry season (Leucaena). Adapted from McLennan (2014). 
towards the end of the growth path, when the difference between current weight and target weight is known and, thus, a supplement regime can be customised to achieve that.

A Leucaena grass system used at the end of the growth path is just as effective and is more profitable than a supplement regime during the dry seasons of the growth path.

Although not studied, a feedlot finishing system would achieve the same result in that animals, which had followed a pasture-based growth path, could be finished in a feedlot, which would remove or reduce the supplement input over the growth path. In Australia, feedlot finishing of animals is often not economic, but when viewed as part of a total system of production, the whole system can be very economic. In other words, high nutrient input occurs at a discrete short time (70-100 days) at the end of the growth path to reach the target weight and avoids costly and labour-intensive inputs during the growth phase on pasture. Corporate pastoral companies use this approach, but smaller family property units may not be able to access such a system without externally contracting the feedlot phase. However, it addresses the principle of when and with what to supplement or feed and this system targets the very end of the growth phase.

\section{Supplementation strategies}

The decision of a supplement regime should fall into the broader picture of a growth path to slaughter. It may not be necessary to supplement in any case and it is not necessary to maximise live weight gain. Nutritionists always want to meet animal requirements, but animals have evolved to cope with periods of excess and deficiency and a diet which is limiting in one or more nutrients may not be a welfare issue and does not have to be balanced unless the target weight is not being achieved. The first big decision is whether to supplement, given the high cost of a supplement. In Australia, high-cost supplements are often uneconomic and unless they are required within the growth path to a profitable end point, are best not used except for minimal low-cost supplements such as urea. In Brazil, where supplements are much cheaper and a wider range is available, the result appears be very different (Dórea, 2010; Detmann et al., 2014; Barbero et al., 2015; De Oliveira et al., 2016).

The supplement regime needs to be characterised by response curves so that seasonal and supplement types can be delineated. The response curves also allow economic evaluation of the level of supplement and are more generalised to a number of circumstances so as to be more universal in their usefulness. The response curves need to be defined for animals of different weight to be applicable to animals at different stages of the growth curve.

McLennan (1997) defined the response to supplement type by season in northern Australia, Poppi et al. (1997) collated responses to supplements for basal forages of high and low quality, and Dórea (2010), Detmann et al. (2014), Barbero et al. (2015), and De Oliveira et al. (2016) collated or developed response curves over the wet and dry seasons of Brazil (Figure 5).

In the wet season, a large amount of supplement needs to be applied to get a sufficiently large live weight gain response to achieve a large enough difference to impact on the growth path in that period. The response to protein mealor energy-based supplements differs by season with the dry season showing a larger response to low levels of protein meals. This work concluded that, within the Australian scene, there is no basis for wet season supplementation as the response is too low or conversely very large amounts of supplement are needed to get a realistic increase in live weight gain. The results from Brazil are very similar to Australia in pattern and quantitative response and, given the difference in pasture base between these studies, this gives confidence in the use of the response curves that have been developed. In the dry season, there is a greater response to low levels of protein meal- compared with energy-based supplements (McLennan, 1997, 2002, 2005) (Figures 5 and 6), but at high levels, there was little difference between the supplement types. This led to the recommendations of protein meal or combinations of protein meals and energybased supplements depending on the level of supplement

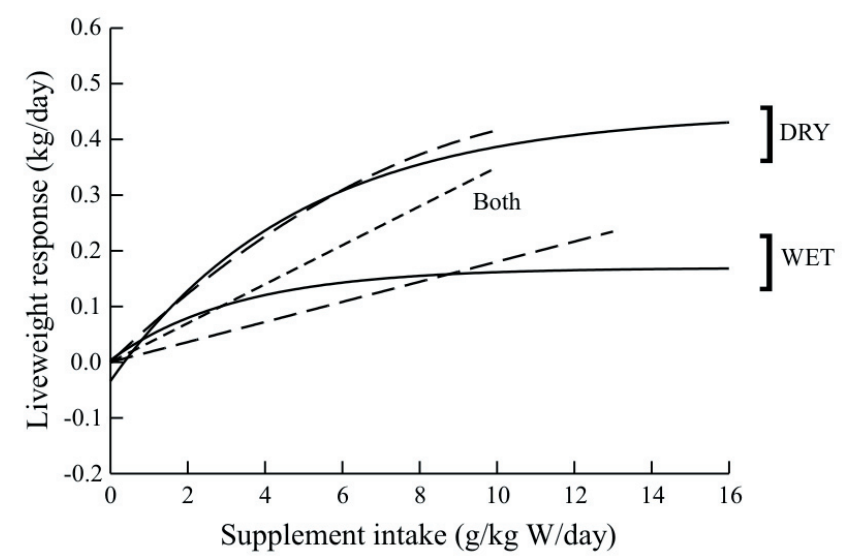

Figure 5 - Effects of intake of supplement on the liveweight response (gain relative to unsupplemented steers) by steers during the dry (top set of lines) and wet (bottom set) seasons, compiled by S. R. McLennan and D. P. Poppi, unpublished data and McLennan (1997) (solid lines) and Dórea (2010; long-dashed lines), and across both seasons (short-dashed line) compiled by Detmann et al. (2014). 
and the target live weight gain response (Figure 6), and should be formulated on the basis of the composition of the pasture base and the likely response of the animal to deliver rumen-degradable protein, metabolisable protein, and metabolisable energy required for the target live weight gain. This response is based on the best combinations to increase metabolisable protein and metabolisable energy supply, in which, with dry season pasture, CP is low and is the first limiting nutrient and, therefore, high levels of CP content are needed at low levels of supplementation; however, at higher levels of supplementation, the supplement can be formulated to meet rumen-degradable protein, metabolisable protein, and metabolisable energy requirements.

The weight of steer being supplemented also affects the response curve, but not as large an effect as might be expected. In these studies, it is important to choose animals that reflect the stage within the growth curve being studied, i.e. weaner around $200 \mathrm{~kg}$ vs steer or bull in finishing phase around $400 \mathrm{~kg}$. McLennan et al. $(2017 \mathrm{a}, \mathrm{b})$ recently published a series of papers which concluded that the live weight gain response $(\mathrm{kg} / \mathrm{day})$ of younger and older steers is the same to absolute level of supplement ( $\mathrm{kg} /$ day); this is
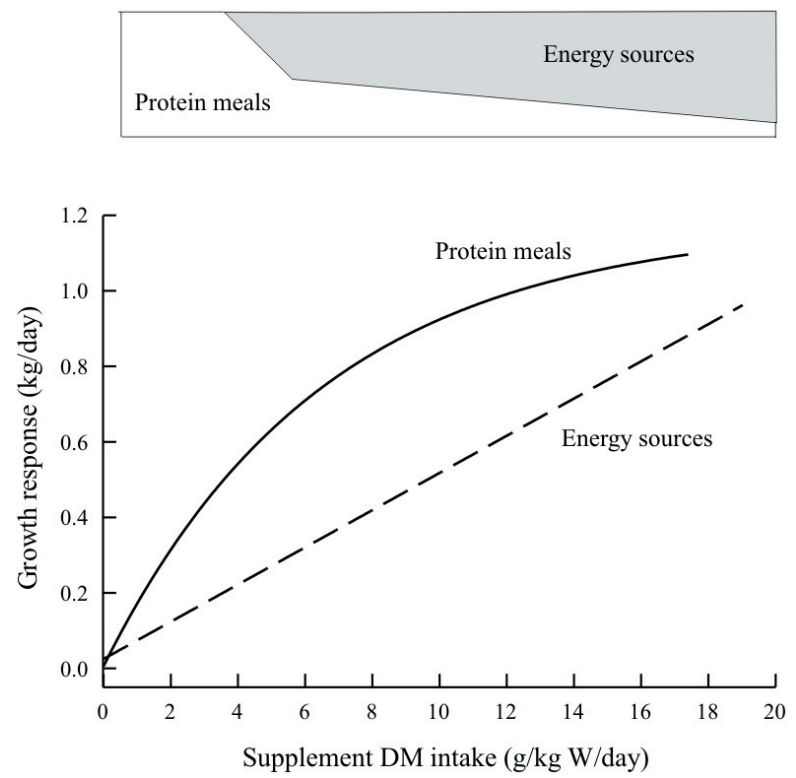

A graphical representation of the possible transition from feeding primarily protein meals to primarily energy sources, with increasing supplement intake, to exploit the higher response to protein meals at low intake and the lower cost of energy sources, is provided in the illustration at the top of the figure.

Figure 6 - Representative growth responses (gain relative to unsupplemented steers) by steers receiving a basal diet of low-quality tropical hay forage to protein meals and 'energy sources', compiled from a series of pen feeding trials (McLennan, 2005; McLennan et al., 2017a,b). unexpected, given the literature which suggests that stage of growth and variation in protein and fat deposition with stage of growth would influence live weight response of younger and older steers to supplements. The difference is that the age and weight were chosen in their experiments to reflect the difference in the growth path rather than older animals being closer to maturity. Thus, the difference between these two classes of animals reflect their stage of growth within the first dry season and the second dry season moving into the finishing phase and clearly shows that the responses derived by McLennan (1997, 2002, 2005, 2014) (Figures 5 and 6), largely for weaners of $200 \mathrm{~kg}$, can be applied to $400-\mathrm{kg}$ animals to make the right decision as to whether to supplement and with what type of supplement.

All these results show that supplements can be overused by nutritionists wanting to meet animal requirements rather than whether they are economic within a growth curve. The detailed response curve relationships enable one to make correct decisions based on economic and not purely biological grounds. In Brazil, supplements seem to be used widely and at low levels and the basis for the response and need is not clear in all cases. Similarly, the basal pasture is of higher $\mathrm{CP}$ than the dry season in Australia or has a much shorter period when CP is low (Dórea, 2010; Detmann et al., 2014; Barbero et al., 2015; De Oliveira et al., 2016), and once again, the need for a supplement in all cases must be questioned. Winks and Laing (1972) showed that urea supplements did not increase live weight gain until faecal $\mathrm{CP}$ fell below $8 \% \mathrm{CP}$. Calculations based on faecal nearinfrared spectroscopy (NIRS) to measure $\mathrm{CP}$, which use feeding standard values for microbial protein production taking into account urea recycling, suggest that the $\mathrm{CP}$ of the pasture needs to be very low before meaningful live weight gain responses are seen (Poppi et al., 1997). McLennan $(1997,2005,2014)$ developed simple excel calculators that can be used in association with faecal NIRS to determine when a response is likely to occur. A commercial NIRS service is offered in Australia for producers to establish the seasonal pattern of $\mathrm{CP}$ and digestibility on their own farm and to take a sample at any point in time or paddock to ascertain if a response to a supplement will occur and what type of supplement would best meet the growth path target. Doing nothing, even though the live weight gain might be low, could be the best strategy. A similar approach might be useful in Brazil.

Supplements cause substitution to varying degrees depending on the $\mathrm{CP}$ content of the basal diet (McLennan et al., 2017a,b). Low-CP forages $(<7 \% \mathrm{CP})$ show a marked increase in intake to a protein meal supplement up to a 
supplement level of $5 \mathrm{~g} / \mathrm{kg} \mathrm{W} /$ day and, thereafter, a classical substitution effect is seen (McLennan et al., 2017a,b). This can be accommodated by using the response curves and the energy use equations in feeding standards and simplified for use in Quikintake (McLennan, 1997, 2005 , 2014). Using this approach to calculate intake of pasture when supplement intake is known, the Quikintake calculator was used by McLennan (2014) to look at the substitution effect of supplements within a growth path (as outlined in Figure 4; Table 1). Thus, substitution can be used when pasture is short or to increase stocking rate to achieve the same end point and this is valuable management flexibility.

\section{Specialised pasture systems}

The collation of work by Winter et al. (1991) also showed the roles of legumes in a pasture system, which are to improve the nutritional value and add $\mathrm{N}$ to the soil. In Australia, legume introduction generally results in an increase in annual live weight gain of $60 \mathrm{~kg}$. Maintenance of a legume under grazing conditions is difficult for tropical legumes and that has hindered their use. Other systems with tree legumes such as leucaena offer advantages in resilience to grazing and longevity. They can be used in intensive rotational systems (Petty et al., 1998; Petty and Poppi, 2008,2012 ) or as special-purpose pastures for discrete periods (Figure 4) (McLennan, 2014). It was shown to be the most profitable option for a discrete finishing period at the end of the growth path (McLennan, 2014).

Other systems, such as fodder crops of grasses (e.g. oats) or legumes (e.g. Dolichos lab lab), also offer opportunities (Bowen et al., 2015). Nevertheless, the challenge in growth paths under tropical pastures is to find a high-energy or highprotein source that can be grown on farm. In Australia, any external feed source soon rapidly acquires a commercial value set by its energy or protein value as ruminants compete with monogastric intensive industries. This makes them uneconomic in many circumstances. Brazil has advantages in having many byproducts of high nutritional value at low cost compared with other parts of the world. Hence, using these is an appropriate strategy, especially if the amounts recommended are based on response curve relationships. In Australia, the search continues for high metabolisable energy or crude protein feed sources that could be grown on farm. Pasture legumes offer one strategy, but the responses, whilst significant, are relatively small with the exception of leucaena. A source of energy or protein of low cost and high yields is required if there is a major increase in production. There is emerging interest in crops such as fodder beet and cassava for high metabolisable energy and algae (Panjaitan et al., 2015; Costa et al., 2016) for protein in developing these new systems.

\section{Weaning weight}

The development of a growth path has an end point of weight for age, but it has variable start weights at weaning. Early weaning down to $70-100 \mathrm{~kg}$ is recommended in some circumstances to reduce nutrient demand by the cow and maintain its body condition score for high reproduction rates and survival (Stockwell et al., 1991). This is especially important in extensive large cattle properties in northern Australia. However, the end result of the weaning process is to have calves that vary in weight from 100 to $200 \mathrm{~kg}$. Over the two-year time frame of reaching a target weight, this extra $100 \mathrm{~kg}$ has to be achieved. Thus, the dry season supplement regime needs to achieve a higher live weight gain and, therefore, a higher level of supplement is needed either in both or in one of the dry seasons. This is why response curves are useful as the target weight gain in any season may vary depending on the entry weight of the animal into that season and the original weaning weight (Table 2).

Recently, Silva (unpublished $\mathrm{PhD}$ data) has shown in the Northern Territory that weaners of 130 or $200 \mathrm{~kg}$ responded similarly to increasing intake of a corn-copra meal supplement in the first dry season showing no effect of weaning weight on response to supplement. In the first dry season, if both groups of weaners were fed a low crude protein hay $(4 \% \mathrm{CP})$ with only a urea supplement and then allowed to graze seasonal pastures over the next

Table 1 - Pasture and supplement intake of steers supplemented in both dry seasons (H-H), second dry season only (L-H), or receiving no supplement (L) until target weight of approximately 550-600 kg reached

\begin{tabular}{lcc}
\hline Growth path & $\begin{array}{c}\text { Pasture intake } \\
\text { (tonnes dry matter for whole growth path) }\end{array}$ & $\begin{array}{c}\text { Supplement intake } \\
\text { (tonnes dry matter for whole growth path) }\end{array}$ \\
\hline L pasture only with urea supplement & 8.77 & 0.01 \\
L-H & 4.15 & 0.85 \\
H-H & 4.29 & 1.09 \\
\hline
\end{tabular}

Values calculated by Quikintake calculator (McLennan, 1997, 2005, 2014) and equations based on NRDR (2007). 
Table 2 - Effect of weaning weight on the extra inputs required to reach a target weight of $550 \mathrm{~kg}$ at 2.5 years of age from the intermediate coastal zone of Queensland which on average results in $100 \mathrm{~kg} /$ year live weight gain

\begin{tabular}{lcc}
\hline Weaning weight & $\begin{array}{c}\text { Annual weight gain } \\
(\mathrm{kg})\end{array}$ & $\begin{array}{c}\text { Extra weight gain/year } \\
\text { with supplement }(\mathrm{kg})\end{array}$ \\
\hline 100 & 100 & 125 \\
200 & 100 & 75 \\
\hline
\end{tabular}

2 years, there was no long term consequence (stunting, poor growth) on weaners of low or normal weaning weight. There was still an obvious difference in weight between both groups based on their difference in starting weight and, consequently, there was no stunting or permanent detrimental effect of very-light weight weaners. The main effect was the difference in initial starting weight, which needed to be reduced with supplements if the same target weight was to be achieved at the end of the growth path, as there was no difference between both groups of animals in the subsequent wet season. This has obvious implications in Australia for animals meeting target weights for entry into live export, for steers in a longer-term growth path to slaughter, or to heifers to reach target mating weights to calve at two years.

\section{Skeletal growth}

McLennan (2014) showed that animals continued to grow skeletally, as measured by changes in hip height, even if they were only maintaining weight or losing weight slowly in the dry season (35-39 mm/100 days in dry season vs $62 \mathrm{~mm} / 100$ days in wet season). Thus, under nutritional stress, the skeleton continues to grow slowly. Quigley et al. (2015) showed that under P deficiency, the skeletal elongation rate was reduced and so was growth of the animal largely under the influence of a reduced food intake $(26 \mathrm{~mm} / 100$ days $\mathrm{P}$ deficient diet vs $59 \mathrm{~mm} / 100$ days $\mathrm{P}$ adequate diet). Phosphorus supplementation of a P-deficient diet markedly increased intake, skeletal elongation rate, and live weight gain. The skeletal elongation rate is important because it drives muscle growth (Poppi and McLennan, 2010) and closure of the epiphyseal plates also determines mature frame size and the onset of the fattening phase.

Understanding the factors that control skeletal elongation rate is not well understood. Silva et al. (2014) showed that skeletal elongation rate is very sensitive to energy intake (105 vs 41.7 mm/100 days for high ME intake and high CP intake vs low ME intake and high CP intake), but there is a small biologically insignificant effect by increasing protein intake at low ME intakes (41.7 vs $30.2 \mathrm{~mm} / 100$ days for low ME intake and high $\mathrm{CP}$ intake vs low ME intake and low CP intake). This represents a new area to investigate the effect of pasture types and supplements because it has a carryover effect on compensatory growth in the subsequent wet season. The proposed hypothesis is that achieving a high skeletal elongation rate and, hence, frame size during the dry season will enhance the compensatory growth effect in the subsequent wet season. This remains to be tested and specific nutrient treatments that increase skeletal elongation rate at low levels of energy intake have not yet been successful. McLennan (2014) showed that animals in the dry season deviate from the weight:height relationship so that in the dry season, they have a lower weight:height relationship than animals on a continuous growth trajectory. In practical terms, these animals have a lower body condition score than their continuous growth trajectory contemporaries and these are the animals that are most likely to demonstrate compensatory growth.

\section{Conclusions}

Live weight gain from tropical pastures is low in comparison with temperate pastures. It can be increased through reducing stocking rate, by legume inclusion, and by supplements. Animal responses are too often viewed in isolation of a class of animal, e.g. dry season for weaners, wet season, finishing phase, etc. A better approach is to take a whole of system or growth path approach, which has a starting weight (weaning weight) and a weight for age end point. Different targets will impose different growth targets at the various stages of the growth path. Whether these are achievable, biologically or economically, can only be decided by determining live weight gain for the various pasture systems at the discrete time (wet, dry, etc) or the responses to supplements (type and season). This enables various growth paths to be constructed and tested. Real time weight monitoring at discrete key times (e.g. transition between season) or preferably through regular real-time monitoring through remote auto-weighing systems enables decision points to be reached along the target growth path. Growth paths can be compared economically rather than on highest live weight gain; but more importantly, a weight recorded at one point in time leads to decisions about what to do to achieve a target terminal weight for age at a later date and whether this is achievable. Compensatory growth along the growth path and weaning weight are major factors influencing whether a target growth path is economical or feasible. Such analysis to date indicates that real time monitoring of weight and high input towards the end of the 
growth path better define the responses which are required by any intervention at that stage. These interventions currently might be the high level of supplement only in the second dry season, leucaena-based systems for a discrete finishing period at the end of the pasture phase, or feedlot finishing, the economics of which depend on entry weight and, hence, the length of time required in the feedlot to meet market specifications. Novel protein and/or high energy crops offer another solution.

\section{References}

Barbero, R. P.; Malheiros, E. B.; Araujo, T. L. R.; Nave, R. L. G.; Mulliniks, J. T.; Berchielli, T. T.; Ruggieri, A. C. and Reis, R. A. 2015. Combining Marandu grass grazing height and supplementation level to optimise growth and productivity of yearling bulls. Animal Feed Science and Technology 209:110-118.

Black, J. L. 2014. Brief history and future of animal simulation models for science and application. Animal Production Science 54:1883-1895.

Bowen, M.; Chudleigh, F.; Buck, S.; Hopkins, K. and Brider, J. 2015. Final Report, B.NBP.0636, High-output forage systems for meeting beef markets-Phase 2. Meat and Livestock Australia, 335p.

Costa, D. F. A.; Quigley, S. P.; Isherwood, P.; McLennan, S. R. and Poppi, D. P. 2016. Supplementation of cattle fed tropical grasses with microalgae increases microbial protein production and average daily gain. Journal of Animal Science 94:2047-2058.

De Oliveira, A. P.; Casagrande, D. R.; Bertipaglia, L. M. A.; Barbero, R. P.; Berchielli, T. T.; Ruggieri, A. C. and Reis R. A. 2016. Supplementation for beef cattle on Marandu grass pastures with different herbage allowances. Animal Production Science 56:123-129.

Detmann, E.; Valente, E. E. L.; Batista, E. D. and Huhtanen, P. 2014. An evaluation of the performance and efficiency of nitrogen utilization in cattle fed tropical grass pastures with supplementation. Livestock Science 162:141-153.

Dórea, J. R. R. 2010. Níveis de suplemento energético para bovinos em pastagens tropicais e seus efeitos no consumo de forragem e fermentação ruminal. Dissertação (M.Sc.). Escola Superior de Agricultura Luiz de Queiroz, Universidade de São Paulo, Piracicaba.

Gramshaw, D. and Lloyd, D. 1993. Grazing the North: creating wealth and sustaining the land. A report for The State of Queensland (acting through Queensland Department of Primary Industries).

Hunt, L.; Petty, S.; Cowley, R.; Fisher, A.; White, A.; MacDonald, N.; Pryor, M.; Ash, A.; McCosker, K.; McIvor, J. and MacLeod, N. 2013. Final Report B.NBP.0375, Sustainable development of the Victoria River District (VRD) grazing lands. Meat and Livestock Australia. 448p.

McCown, R. L. 1981. The climatic potential for beef cattle production in tropical Australia: Part 1-simulating the annual cycle of liveweight change. Agricultural Systems 6:303-307.

McLennan, S. R. 1997. Final Report DAQ.100, Developing profitable strategies for increasing growth rates of cattle grazing tropical pastures. Meat and Livestock Australia. 109p.

McLennan, S. R. 2002. Final Report NAP3.122, More effective supplements for the northern beef industry. Meat and Livestock Australia. 97p.

McLennan, S. R. 2005. Final Report NBP.331, Improved prediction of the performance of cattle in the tropics. Meat and Livestock Australia. 40p.
McLennan, S. R. 2014. Final Report B.NBP.0391, Optimising growth paths of beef cattle in northern Australia for increased profitability. Meat and Livestock Australia. 182p.

McLennan, S. R.; Bolam, M. J.; Kidd, J. F.; Chandra, K. A. and Poppi, D. P. 2017a. Responses to various protein and energy supplements by cattle fed low-quality tropical hay. 1. Comparison of response surfaces for young steers. Animal Production Science 57:473-488. https://doi.org/10.1071/AN15659

McLennan, S. R.; Campbell, J. M.; Pham, C. H.; Chandra, K. A.; Quigley, S. P. and Poppi, D. P. 2017b. Responses to various protein and energy supplements by steers fed low-quality tropical hay. 2 . Effect of stage of maturity of steers. Animal Production Science 57:489-504. https://doi.org/10.1071/AN15660

NRDR. 2007. Nutrient requirements of domesticated ruminants. CSIRO Publishing, Melbourne, Australia.

O'Reagain, P.; Bushell, J. and Holmes, B. 2011. Managing for rainfall variability: long term profitability of different grazing strategies in a northern Australian tropical savannah. Animal Production Science 51:210-224.

Panjaitan, T.; Quigley, S. P.; McLennan, S. R.; Swain, A. J. and Poppi, D. P. 2015. Spirulina (Spirulina platensis) algae supplementation increases microbial protein production and feed intake and decreases retention time of digesta in the rumen of cattle. Animal Production Science 55:535-543.

Petty, S. R.; Poppi, D. P. and Triglone, T. 1998. Effect of maize supplementation, seasonal temperature and humidity on the liveweight gain of steers grazing irrigated Leucaena leucocephala/ Digitaria eriantha pastures in north-west Australia. Journal of Agricultural Science (Cambridge) 130:95-105.

Petty, S. R. and Poppi, D. P. 2008. Effect of muddy conditions in the field on the liveweight gain of cattle consuming Leucaena leucocephala/Digitaria eriantha pastures in north-west Australia. Australian Journal of Experimental Agriculture 48:818-820.

Petty, S. R. and Poppi, D. P. 2012. The liveweight gain response of heifers to supplements of molasses or maize while grazing irrigated Leucaena leucocephala/Digitaria eriantha pastures in north-west Australia. Animal Production Science 52:619-623.

Poppi, D. P.; McLennan, S. R.; Bediye, S.; de Vega, A.; Zorilla-Rios, J. 1997. Forage quality: Strategies for increasing nutritive value of forages. p.307-322. In: Proceedings of the XVIII International Grassland Congress, Winnipeg and Sakatoon, Canada. Canadian Forage Council, Canadian Society of Agronomy, Canadian Society of Animal Science, Association Management Centre (1999). Buchanan-Smith, J. G.; Bailey, L. D.; and McCaughey, P., eds.

Poppi, D. P. and McLennan, S. R. 2010. Nutritional research to meet future challenges. Animal Production Science 50:329-338.

Quigley, S. P.; Poppi, D. P. and Schatz, T. 2015. Final Report B.NBP.0537, Validation and demonstration of a diagnostic tool for phosphorus status of beef cattle. Meat and Livestock Australia, $126 \mathrm{p}$.

Silva, T. A. C. C.; Quigley, S. P.; Kidd, L. J.; McLennan, S. R. and Poppi, D. P. 2014. Skeletal growth, liveweight gain, and feed intake of Bos indicus and Bos taurus cattle undergoing compensatory liveweight gain. Proceedings of the Australian Society of Animal Production 30:289.

Stockwell, T. G. H.; Smith, P. C.; Stafford Smith, D. M. and Hirst, D. J. 1991. Sustaining productive pastures in the tropics 9. Managing cattle. Tropical Grasslands 25:137-144.

Winks, L. and Laing, A. R. 1972. Urea, phosphorus and molasses supplements for grazing beef weaners. Proceedings of the Australian Society of Animal Production 9:253-255.

Winter, W. H.; Winks, L. and Seebeck, R. M. 1991. Sustaining productive pastures in the tropics 10. Forage and feeding systems for cattle. Tropical Grasslands 25:145-152. 